○第 55 回ゴム技術進歩学受学者報告○

\section{圧縮永久ひずみの最小の熱可塑 性弾性体}

横浜ゴム株式会社

研究本部第 4 研究 $G$

渡䢬次郎

横浜ゴムは 97 年 4 月にゴムとプラスチッ クの長所を併せ持つ新しい熱可塑性材料群 ・ Velaren ${ }^{\circledR} の$ 技術を発表しました。

Velaren とは一般に“動的加硫”と呼ばれて いる混練・加硫技術を多種多様なゴムと熱可 塑性樹脂 (以下，樹脂という)の組み合わせに 対して汎用的に適用させたもので，優れたゴ 厶弾性，耐熱軟化性と樹脂の加工性，リサイ クル性を併せ持つ新しいゴム材料のことで す.

Velarenの開発にあたっては様々なゴムと 樹脂を組み合わせて種々の製品にふさわしい 特性を発現する配合技術と混練・加硫を一体 的に行う混練技術を新たに開発する必要があ クました。モルフォロジー的にはV Velarenの 構造は樹脂のマトリクス中にゴムが微細な粒 子状に分散し，かつこのゴム相が加硫した構 造をとっています。この分散構造により加硫 ゴムのゴム弾性と樹脂の加工性が両立できる ことになります。

\section{低圧縮永久ひずみを有する熱可塑性弾性体 の技術}

今回受賞の低圧縮永久ひずみを有する熱可 塑性ポリエステル系弾性体はこの Velarenの 技術を使って樹脂が連続相，加硫ゴムが分散 相の海島構造をとりながら分散相の加硫ゴム の量をできるだけ増やすことで対応してみま した.

技術的には多量のゴムでも樹脂がくるむよ うに混練時のゴムと樹脂の粘度を調整し，か つ化学反応を利用した相溶化手法でゴムを微 細に分散することでゴム量増を達成しました。

更に混練と加硫を一体的に行う動的加硫に

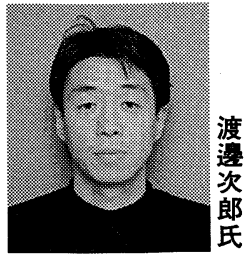

おいて，樹脂中に細かく分散させたゴム相を 短時間のうちに効率よく加硫させることが低 圧縮永久ひずみを達成するポイントでした。

こうして作製したポリエステル系 Velaren は JIS A 硬度 $75,100^{\circ} \mathrm{C} \cdot 22 \mathrm{~h}$ の圧縮永久U ずみが $29.5 \%$ (当社測定値) と熱可塑性の加工 ができる材料でありながら加硫ゴムに匹敵す る物性を得ることができました。

このような基本技術を組み合わせることに より今まで限られたゴムと樹脂の組み合わせ のみで一部実用化されていた技術が制御可能 な汎用的領域にまで拡大することができたと 考えています.

\section{Velaren 技術の応用について}

当社ではこれまで培ってきた各種ゴム製品 の設計技術により，Velarenの特性を有効に 使った新規商品への応用を進めています。

例之ば，柔軟かつ高強度で熱融着が可能な 土木遮水シート，良好なゴム弾性によって $120^{\circ} \mathrm{C}$ までの繰り返しの温度変化にも耐えう る高温高圧ホース. 飛距離とスピン性能を両 立させたカバー材料を使ったゴルフボール。

更には昨年 10 月発表の空気透過性をブチル

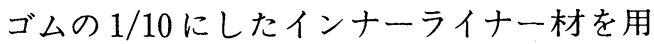
いて商品化予定の軽量化夕イヤ等です。

今回受賞のポリエステル系 Velarenも, こ れらの技術を応用したものであり，開発担当 として本賞を頂けたことは今後の大きな励み となりました。本技術を生かし，更に進めて リサイクル，省エネルギ一等の環境課題を克 服する新しいゴム製品の進歩に少しでも貢献 できるよう努力していく所存です. 